\title{
Myocardial Inflammatory Cell Infiltrates in Cases of Dilated Cardiomyopathy as a Determinant of Outcome Following Partial Left Ventriculectomy
}

\author{
Yumiko Kanzaki, MD; Fumio Terasaki, MD; Makoto Okabe, MD; \\ Tetsuya Hayashi, MD; Haruhiro Toko, MD; Hiroaki Shimomura, MD; \\ Shigekazu Fujioka, MD; Yasushi Kitaura, MD; Keishiro Kawamura, MD; \\ Yasuhiro Horii, MD*; Tadashi Isomura, MD*; Hisayoshi Suma, MD*
}

\begin{abstract}
Partial left ventriculectomy (PLV) can be used to treat refractory congestive heart failure caused by dilated cardiomyopathy (DCM). In order to understand the relationship between the underlying myocardial injury and early clinical outcomes after PLV, histopathologic, immunohistochemical and virologic studies of the resected myocardium were performed. The posterolateral left ventricular walls from 27 patients with idiopathic DCM were examined. Cardiomyocyte diameter, degree of myocardial fibrosis, degree of cardiomyocyte degeneration, and degree of inflammatory cell infiltration were compared with mortality rates. Polymerase chain reaction was performed to detect enterovirus genome in the myocardium. Some patients had inflammatory cell infiltrates with focal accumulations of lymphocytes and macrophages, including both cytotoxic/suppressor T-cells and helper/inducer T-cells. The number of inflammatory cells (activated lymphocytes plus macrophages $/ \mathrm{mm}^{2}$ ) was significantly greater in patients who died of cardiac insufficiency after surgery $(27.8 \pm 5.7 ; n=7)$ than in the survivors $(11.1 \pm 2.5 ; n=15)$. There was no significant difference in the degree of myocardial fibrosis, cardiomyocyte diameter or degree of cardiomyocyte degeneration between the 2 groups. Enterovirus genome was detected in the myocardium of $9(38 \%)$ of 24 patients examined and 5 of these enterovirus-positive hearts had severe inflammatory cell infiltrates $\left(37.9 \pm 2.5 / \mathrm{mm}^{2}\right)$. Early survival in patients undergoing PLV for DCM is significantly affected by the degree of myocardial inflammation, so patients with more severe or ongoing inflammation may have poor clinical outcomes. Chronic myocarditis may play an important role in the etiology and pathophysiology of idiopathic DCM. (Jpn Circ J 2001; 65: 797-802)
\end{abstract}

Key Words: Dilated cardiomyopathy; Myocardial inflammation; Partial left ventriculectomy; Pathology

$\mathbf{H}$ eart transplantation has been used to treat dilated cardiomyopathy (DCM) in patients in whom medical therapy or a left ventricular assist device has failed. However, there are a limited number of hearts available for transplantation, and many patients die while awaiting transplantation. Recently, partial left ventriculectomy (PLV; the Batista procedure) $)^{1-6}$ has received attention as an alternative or bridging treatment for severe cardiomyopathies. In this operation, the surgeon partially resects the left ventricle in an attempt to decrease left ventricular wall tension by reducing chamber volume. Therefore it is necessary to establish the indications for this procedure and to determine the prognosis following this surgery.

Immunologic abnormalities, viral infections, and genetic predisposition are possible factors involved in the development of myocardial injury in DCM? The presence of inflammatory cell infiltrates ${ }^{8-11}$ and viral genomes ${ }^{12-15}$ in

(Received October 27, 2000; revised manuscript received May 28, 2001; accepted June 11, 2001)

The Third Division, Department of Internal Medicine, Osaka Medical College, Takatsuki and $*$ Division of Cardiovascular Surgery, Hayama Heart Center, Hayama, Kanagawa, Japan

Part of this study was presented at the $22^{\text {nd }}$ Congress of the European Society of Cardiology.

Mailing address: Fumio Terasaki, MD, The Third Division, Department of Internal Medicine, Osaka Medical College, 2-7 Daigaku-machi, Takatsuki 569-8686, Japan. E-mail: in3012@poh.osaka-med.ac.jp myocardial biopsy specimens have been reported in the setting of DCM. Furthermore, autopsy specimens of hearts from patients with DCM have evidence of inflammatory cell infiltrates ${ }^{16,17}$ It is therefore quite important to determine the role of inflammatory cell infiltrates or active myocarditis in the development of DCM.

The histopathologic features of myocardial injury and the severity of cardiomyopathy are considered to be factors determining the prognosis following PLV. We previously reported that severe inflammatory cell infiltration might serve as a predictor of poor outcome ${ }^{18,19}$ but we could not determine a significant correlation between any histopathologic findings and the early prognosis of patients with DCM following PLV, because the number of patients was too small.

The purpose of present study was to determine the involvement of active myocarditis in DCM using histopathologic, immunohistochemical and virologic studies of myocardial specimens obtained by PLV. In addition, this study aimed to determine the relationship between the histopathologic findings and the early prognosis of patients with DCM following PLV using more histopathologic factors in a larger number of cases compared with our previous study! 18,19 
Table 1 Individual Data for 27 Patients With Dilated Cardiomyopathy Who Underwent Partial Left Ventriculectomy

\begin{tabular}{|c|c|c|c|c|c|c|c|c|}
\hline \multirow{2}{*}{ Patient no. } & \multirow{2}{*}{ Age/sex } & \multirow{2}{*}{ Prognosis } & \multirow{2}{*}{ \% fibrosis } & \multicolumn{3}{|c|}{ Cell infiltration $\left(/ \mathrm{mm}^{2}\right)$} & \multirow{2}{*}{$\begin{array}{c}\text { Enterovirus } \\
\text { genomes }\end{array}$} & \multirow{2}{*}{$\begin{array}{l}\text { Cardiomyocyte } \\
\text { diameter }(\mu \mathrm{m})\end{array}$} \\
\hline & & & & $L C A$ & CD68 & Total & & \\
\hline 1. & $53 M$ & $N C$ & 26.7 & 10.8 & 9.5 & 20.3 & $N D$ & 19.50 \\
\hline 2. & $43 F$ & $A$ & 33.1 & 8.1 & 2.7 & 10.8 & $N D$ & 19.74 \\
\hline 3. & $56 M$ & A & 31.1 & 28.9 & 9.8 & 38.7 & Positive & 21.64 \\
\hline 4. & $43 M$ & A & 26.6 & 17.9 & 10.8 & 28.7 & Positive & 22.86 \\
\hline 5. & $60 M$ & $A$ & 38.7 & 2.1 & 7.3 & 9.4 & & 21.96 \\
\hline 6. & $55 M$ & $A$ & 29.2 & 6.8 & 3.7 & 10.5 & & 22.51 \\
\hline 7. & $16 M$ & C & 41.4 & 33.0 & 7.5 & 40.5 & Positive & 17.60 \\
\hline 8. & $48 F$ & $N C$ & 16.3 & 10.2 & 9.6 & 19.8 & & 21.27 \\
\hline 9. & $65 M$ & $A$ & 9.3 & 4.4 & 4.2 & 8.6 & & 19.01 \\
\hline 10. & $64 F$ & $C$ & 10.8 & 6.0 & 4.1 & 10.1 & Positive & 24.41 \\
\hline 11. & $67 M$ & $N C$ & 6.8 & 2.5 & 1.4 & 3.9 & & 18.59 \\
\hline 12. & $61 M$ & $C$ & 12.0 & 24.3 & 11.0 & 35.3 & & 19.10 \\
\hline 13. & $14 M$ & C & 7.9 & 24.7 & 9.5 & 34.2 & Positive & 17.36 \\
\hline 14. & $49 M$ & C & 5.5 & 7.5 & 5.0 & 12.5 & & 18.36 \\
\hline 15. & $53 M$ & $N C$ & 5.6 & 32.8 & 5.0 & 37.8 & Positive & 18.97 \\
\hline 16. & $25 M$ & $A$ & 4.3 & 2.7 & 1.7 & 4.4 & & 19.68 \\
\hline 17. & $47 M$ & A & 2.2 & 7.3 & 1.4 & 8.7 & $N D$ & 19.23 \\
\hline 18. & $36 M$ & $C$ & 14.0 & 33.0 & 14.3 & 47.3 & Positive & 18.10 \\
\hline 19. & $22 F$ & $C$ & 29.8 & 10.6 & 4.1 & 14.7 & & 22.30 \\
\hline 20. & $40 M$ & A & 6.7 & 5.0 & 2.9 & 7.9 & Positive & 18.35 \\
\hline 21. & $57 F$ & $A$ & 23.2 & 3.3 & 1.0 & 4.3 & & 18.46 \\
\hline 22. & $51 F$ & $N C$ & 15.3 & 10.2 & 19.9 & 30.1 & & 19.41 \\
\hline 23. & $38 M$ & $A$ & 11.9 & 2.9 & 1.0 & 3.9 & & 18.46 \\
\hline 24. & $42 M$ & A & 15.5 & 2.9 & 6.6 & 9.5 & Positive & 20.75 \\
\hline 25. & $47 M$ & $A$ & 24.1 & 3.9 & 5.0 & 8.9 & & 21.90 \\
\hline 26. & $55 M$ & A & 9.8 & 3.1 & 1.4 & 4.5 & & 21.12 \\
\hline 27. & $57 F$ & A & 27.2 & 4.6 & 2.9 & 7.5 & & 20.33 \\
\hline
\end{tabular}

A, alive; $C$, cardiogenic death; $N C$, noncardiogenic death; $N D$, not done.

\section{Methods}

Twenty-seven consecutive patients with idiopathic DCM (20 men, 7 women; mean age, $47 \pm 14$ years) who underwent PLV between December 1996 and July 1998 at the Shonan Kamakura General Hospital or Osaka Medical College Hospital, Japan were enrolled. The clinical diagnosis of DCM was made according to the World Health Organization/International Society and Federation of Cardiology Task Force? Assessment of symptoms of heart failure was performed using the New York Heart Association (NYHA) functional classification 20 All patients underwent noninvasive and invasive evaluation, including echocardiography and cardiac catheterization with coronary angiography. In 8 patients, an endomyocardial biopsy from the right ventricle was performed before the operation, but there was no evidence of significant infiltration of inflammatory cells. Institutional reviews board approval was obtained at both hospitals, and all patients gave informed consent for inclusion in the study. Specimens of ventricular myocardium from the posterolateral wall that were resected during the surgery were analyzed.

\section{Histopathologic Examination}

Specimens were fixed in $10 \%$ buffered formalin and embedded in paraffin for routine light microscopy. Transmural sections $\left(1.5-4.0 \mathrm{~cm}^{2}\right)$ were prepared. Hematoxylin-eosinstained sections were analyzed for the semiquantitative grading (0-4) of cardiomyocyte degeneration, including scarcity of myofibrils and vacuolization. ${ }^{1}$ For each specimen, photomicrographs (magnification: $\times 100$ ) of 20 randomly selected fields were obtained for the outermost, intermediate, and innermost layers of the myocardium (60 visual fields per specimen in total). Quantitative analysis of myocardial cell diameter was performed using NIH Image analysis software. Azan-stained sections were used for quantitative evaluation of the degree of interstitial fibrosis (\% fibrosis) using the point counting method 22

\section{Immunohistochemical Examination}

Paraffin sections (prepared from 10\% buffered formalinfixed specimens) or frozen sections (prepared from frozen specimens using a cryomicrotome [Reichert-Jung 2800E]) were examined as follows. First, inflammatory cell infiltration was evaluated qualitatively using leukocyte surface markers (LCA [lymphocytes], UCHL-1 [activated memory T cells], OPD4 [helper/inducer T cells], CD8 [cytotoxic/ suppressor T cells], SL-26 [B cells], CD68 [macrophages] and Leu7 [natural killer cells]; purchased from Dako Japan, Tokyo, Japan). Quantitative evaluation of inflammatory cell infiltration also used these leukocyte surface markers. For each specimen, photomicrographs (magnification: $\times 100)$ of 20 randomly selected fields were obtained for the outermost, intermediate, and innermost layers of the myocardium (60 visual fields per specimen in total). LCA-positive cells and CD68-positive cells were counted, and the number of inflammatory cells per unit area $\left(1 \mathrm{~mm}^{2}\right)$ was calculated.

\section{Virologic Analyses}

Frozen myocardial specimens were examined for genomes of enteroviruses, including coxsackie virus, mumps virus, cytomegalovirus, influenza A virus, adenovirus, and hepatitis $\mathrm{C}$ virus, using the polymerase chain reaction (PCR) to determine the involvement of viral infection in idiopathic DCM. Details of the PCR methods have been reported previously! ${ }^{14,15,23,24}$ 


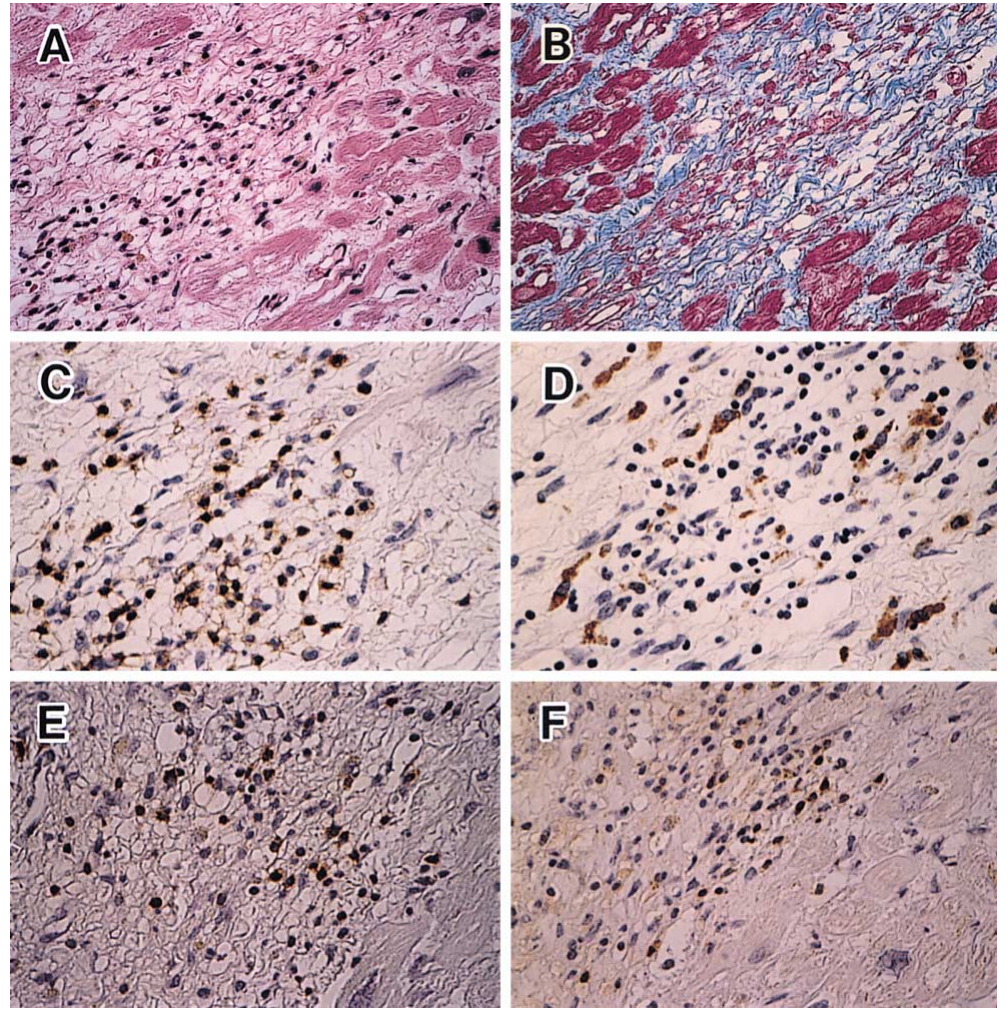

Fig 1. Representative histologic findings of the myocardium of a 36-year-old man (case 18 in Table 1). Severe inflammatory mononuclear cell infiltration with moderate interstitial fibrosis is present (A,B). Myocardial cell degeneration is also visible near the mononuclear cells. Most of the infiltrating cells are LCA-positive lymphocytes (C) and CD68-positive macrophages (D). Both OPD4positive cells (helper/inducer T cells; E) and CD8positive cells (cytotoxic/suppressor T cells; F) are present. (A) Hematoxylin-eosin stain $(\times 100)$; (B) Azan stain ( $\times 100)$; (C-F) Immunostaining for LCA, CD68, OPD4, and CD8, respectively $(\times 160)$. Consecutive sections were used for each staining.

\section{Statistical Analysis}

The relationship between the histopathologic findings and the postoperative outcomes (mortality) was analyzed. All quantitative data are expressed as the mean \pm SE. We used the Mann-Whitney $U$ test to compare the 2 groups with respect to categoric variables. Continuous variables were assessed with Student's unpaired $t$ test for intergroup comparison. A value of $\mathrm{p}<0.05$ was considered significant.

\section{Results}

\section{Histopathologic Examination}

There was evidence of marked myocardial damage; severe interstitial fibrosis, fatty infiltration, and myocardial degeneration were generally observed. The myocardial cell diameter ranged from 17.3 to $24.4 \mu \mathrm{m}$ (mean: $20.0 \pm 0.3 \mu \mathrm{m}$ ) and the severity of myocardial fibrosis (\% fibrosis) ranged from 2.2 to $41.4 \%$ (mean: $18.0 \pm 2.2 \%$ ) (Table 1). Interstitial mononuclear cell infiltration was noted in all of the specimens and was sometimes accompanied by severe interstitial fibrosis and/or myocardial cell degeneration (Fig 1A,B).

\section{Immunohistochemical Examination}

Most of the infiltrating inflammatory cells were LCApositive cells (lymphocytes: range, $2.1-33.0 \mathrm{cells} / \mathrm{mm}^{2}$; mean, $11.4 \pm 2.0$ cells $/ \mathrm{mm}^{2}$ ) and CD68-positive cells (macrophages: range, $1.0-19.9$ cells $/ \mathrm{mm}^{2}$; mean, $6.0 \pm 0.9$ cells $/ \mathrm{mm}^{2}$ ). Leu7-positive cells (natural killer cells) were rarely detected. The total LCA-positive cells and CD68positive cells count ranged from 3.9 to $47.3 \mathrm{cells} / \mathrm{mm}^{2}$ (mean, 17.5 2.6 cells $/ \mathrm{mm}^{2}$ ) (Table 1; Fig 1C,D). In 7 (26\%) of the 27 specimens, the infiltrating inflammatory cell count was greater than 30.0 cells $/ \mathrm{mm}^{2}$. Clusters of infiltrating cells were visible in specimens with severe cell infiltration (Fig 1). UCHL-1-positive cells (T cells) accounted for a higher percentage of the infiltrating lymphocytes than SL-26-positive cells (B cells). Both CD8-positive cells (cytotoxic/suppressor T cells) and OPD4-positive cells (helper/inducer T cells) were detected (Fig 1E,F), and the latter appeared to be more prominent.

\section{Virologic Analysis}

Based on PCR analysis of specimens of resected myocardium, enterovirus genome was present in $9(38 \%)$ of the 24 specimens examined (Table 1 ) and 5 of these enterovirus-positive specimens showed evidence of severe inflammatory cell infiltration ( $>30$ leukocytes $/ \mathrm{mm}^{2}$ ). Mumps virus, cytomegalovirus, influenza A virus, adenovirus, and hepatitis $\mathrm{C}$ virus were not detected.

\section{Histopathologic Features and Prognosis}

When postoperative outcomes within 1 year after surgery were analyzed, 15 of the 27 patients were alive. Many of those patients had resolution of their symptoms. Of the 12 patients who died during this period, 7 died of left ventricular dysfunction after surgery (4 died within 1 month, and 3 died after 1 month). In 5 patients the direct cause of death could not be confirmed as cardiogenic: 2 died of pneumonia, 1 died of cerebral infarction, 1 died of pneumothorax, and 1 died of sudden death (Table 1).

We compared the histopathologic findings between the 7 patients who died of left ventricular dysfunction, 5 patients who died of noncardiogenic causes and the 15 survivors. There was no significant intergroup differences in age, NYHA functional class, preoperative ejection fraction, the degree of myocardial fibrosis, cardiomyocyte diameter, or the degree of cardiomyocyte degeneration (myocardial vacuolization and scarcity) (Table 2).

The 7 patients who died of left ventricular dysfunction had a higher total infiltrating inflammatory cell count than 
Table 2 Clinical Variables and Histological Features of the 7 Patients Who Died of Left Ventricular Dysfunction, the 5 Patients Who Died of Noncardiogenic Causes, and the 15 Survivors

\begin{tabular}{lcccc}
\hline \hline & Survivors & $\begin{array}{c}\text { Cardiogenic } \\
\text { death }\end{array}$ & $\begin{array}{c}\text { Noncardiogenic } \\
\text { death }\end{array}$ & $p$ value \\
\hline Gender (male/female) & $12 / 3$ & $5 / 2$ & $3 / 2$ & \\
Age (years) & $49 \pm 3$ & $37 \pm 8$ & $54 \pm 3$ & $N S$ \\
NYHA class & $3.6 \pm 0.1$ & $3.8 \pm 0.1$ & $3.6 \pm 0.2$ & $N S$ \\
EF $(\%)$ & $18 \pm 2$ & $16 \pm 3$ & $20 \pm 1.6$ & $N S$ \\
\% fibrosis & $19.5 \pm 3.0$ & $17.3 \pm 5.0$ & $14.1 \pm 3.8$ & $N S$ \\
Vacuolization & $2.0 \pm 0.2$ & $2.3 \pm 0.2$ & $2.0 \pm 0.7$ & $N S$ \\
Scarcity & $1.2 \pm 0.1$ & $1.6 \pm 0.3$ & $1.2 \pm 0.2$ & \\
Cardiomyocyte diameter $(\mu \mathrm{m})$ & $20.4 \pm 0.4$ & $19.6 \pm 1.0$ & $20.0 \pm 0.5$ & \\
Cell infiltration $\left(/\right.$ mm $\left.^{2}\right)$ & & & & \\
$\quad$ LCA & $6.9 \pm 1.9$ & $19.9 \pm 4.4^{*}$ & $13.3 \pm 5.1$ & \\
CD68 & $4.2 \pm 0.8$ & $7.9 \pm 1.5^{*}$ & $9.1 \pm 3.1 *$ & \\
Total & $11.1 \pm 2.5$ & $27.8 \pm 5.7^{*}$ & $22.4 \pm 5.7$ & \\
\hline
\end{tabular}

NS, not significant. ${ }^{*} p<0.05$ vs Survivors.

(A) Cell Infiltration

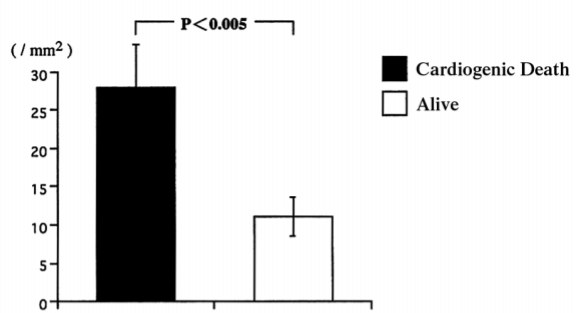

(B) LCA

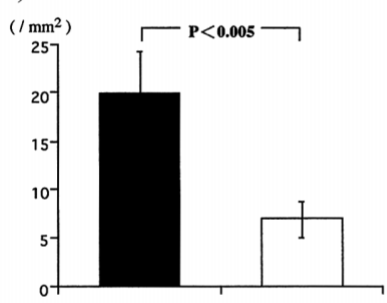

(C) $\mathrm{CD68}$

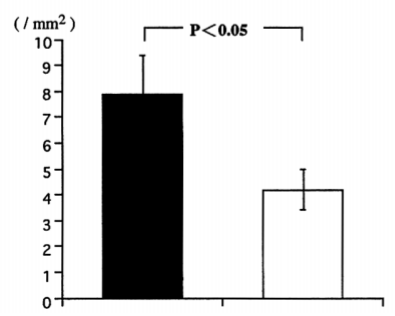

Fig 2. Total number of infiltrating inflammatory cells (A), LCApositive lymphocytes (B) and CD68-positive macrophages (C) in specimens of resected myocardium from patients with idiopathic DCM. Black bars represent patients who died of left ventricular dysfunction after partial left ventriculectomy $(n=7)$, and white bars represent survivors $(n=15)$. Data are expressed as the mean \pm SE.

the 15 survivors $\left(27.8 \pm 5.7\right.$ vs $11.1 \pm 2.5$ cells $/ \mathrm{mm}^{2}, \mathrm{p}=0.0049$; Fig 2A). The intergroup difference was greater for LCApositive lymphocytes $\left(19.9 \pm 4.4\right.$ vs $6.9 \pm 1.9$ cells $/ \mathrm{mm}^{2}$, $\mathrm{p}=0.0044)$ than for CD68-positive macrophages $(7.9 \pm 1.5$ vs $4.2 \pm 0.8$ cells $/ \mathrm{mm}^{2}, \mathrm{p}=0.024$; Fig $\left.2 \mathrm{~B}, \mathrm{C}\right)$. There was no significant difference in the degree of myocardial fibrosis or cardiomyocyte diameter between the 2 groups $(17.3 \pm 5.0$ vs $19.5 \pm 3.0 \%$ and $19.6 \pm 1.0$ vs $20.4 \pm 0.4 \mu \mathrm{m}$, respectively;
(A) Myocardial Fibrosis

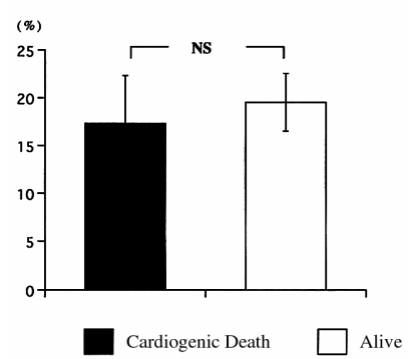

(B) Cardiomyocyte Diameter

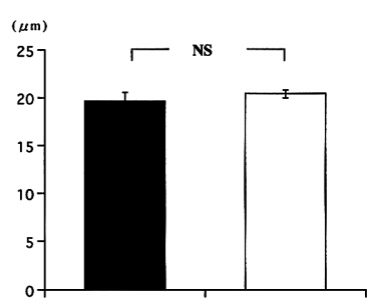

Fig 3. Percent myocardial fibrosis (A) and cardiomyocyte diameter (B) in specimens of resected myocardium from patients with idiopathic DCM. Black bars represent patients who died of left ventricular dysfunction after partial left ventriculectomy $(n=7)$ and white bars represent survivors $(n=15)$. Data are expressed as the mean \pm SE.

Fig 3). The 5 patients who died of noncardiogenic causes had more CD68-positive macrophages than the 15 survivors $\left(9.1 \pm 6.9\right.$ vs $4.2 \pm 0.8$ cells $\left./ \mathrm{mm}^{2}, \mathrm{p}=0.03\right)$. There was no significant statistical difference in the number of LCA-positive lymphocytes and the total cell infiltration (Table 2).

\section{Discussion}

Recently, PLV, as introduced by Batista, has been used for treating end-stage heart disease!,2 In Japan, this procedure was first used in December, 1996, but has had limited success in some institutes $3,4,6$ However, PLV is an acceptably safe and effective treatment for end-stage cardiomyopathy with proper choice of patients 6 We previously reported that severe inflammatory cell infiltration might serve as a predictor of poor outcome in patients with DCM 18,19 and the present study, which included a larger number of patients, demonstrated that the infiltrating inflammatory cell count was significantly greater in patients who died of left ventricular dysfunction after PLV than in patients who survived. Additionally, analysis of the histopathologic factors that might influence outcome showed that early postoperative mortality was affected only by the degree of myocardial inflammation. Based on these findings, anti-inflammatory therapy, including the use of anti-virus and immunosuppressive or immunomodulative agents combined with PLV, might improve the postopera- 
tive outcome in patients with severe or ongoing myocardial inflammation.

In the 5 patients who died of noncardiogenic causes after PLV, the infiltrating inflammatory cell count tended to be higher than in the survivors, although there was no significant statistical difference other than the number of CD68positive macrophages. These cases might have suffered from pneumonia, sudden death or other critical conditions, regardless, because of their left ventricular dysfunction and severe congestive heart failure, possibly associated with an immunologically compromised status. Therefore, in cases of DCM with severe inflammation in the myocardium, early postoperative mortality may be high not only because of cardiogenic death, but also from noncardiac events.

Stolf et al reported that survival after PLV was affected by myocardial cell diameter. Specifically, a greater myocyte diameter was associated with poorer outcomes during the first 7 months following surgery 25 Our study showed no significant difference in the degree of myocardial fibrosis or cardiomyocyte diameter between patients who survived and those who died. These factors seem to contribute less to the early prognosis of patients with DCM after PLV and further long-term follow-up studies are necessary to define their effect.

Myocardial inflammatory cell infiltration is seen in some patients with DCM, and the possible relationship between myocardial inflammation and the etiology and pathophysiology of DCM has received close attention?-11,16,17,26-28 Attempts to treat DCM and myocarditis using immunosuppressive and antiviral agents have been reported $29-33$ In the present study, examination of myocardial specimens obtained by PLV, showed mononuclear cell infiltration in all of the specimens. Quantitative and qualitative analyses using leukocyte surface markers revealed the presence of inflammatory cell infiltrates (active myocarditis) in some cases. Myocardial inflammation in the setting of DCM or chronic myocarditis appears to be a phenomenon that not only takes place in small localized regions of myocardium but is generally present throughout the ventricle 34,35 resulting from the effects of cytokines and adhesion molecules 27,36 Therefore, the inflammatory cell infiltrates present in the resected left ventricular myocardium may reflect the effects of diffuse myocardial inflammation, which strongly suggests that active inflammation is involved in the development of at least some types of DCM, or in terminal-stage DCM. Factors that may induce inflammatory cell infiltration include persistent viral infection, ${ }^{12-15,37}$ autoimmunity ${ }^{38}$ therapeutic use of catecholamines, heart failure, 36 and increased myocardial stress or myocardial ischemia caused by cardiac dysfunction. These primary and secondary factors that may be responsible for inflammatory cell infiltration need to be studied in greater detail.

Based on PCR analysis, enterovirus genome was detected in $9(38 \%)$ of 24 specimens examined and 5 of these enterovirus-positive specimens had evidence of severe inflammatory cell infiltration. The presence of enterovirus genome in the myocardium suggests a role of the virus in the development of myocardial inflammation in the setting of DCM.

\section{Acknowledgments}

The authors wish to express deep gratitude to Prof Shinjiro Sasaki and Dr Keiichiro Kondo, The Department of Cardiovascular Surgery, Osaka Medical College, for their operation of partial left ventriculectomy.

The authors also wish to express deep gratitude to Yoshiro Kitaguni,
Chieko Ota, Akiyo Saito, Sadao Uchida and Ikue Yamamoto for their valuable technical assistance.

This study was supported in part by a grant-in-aid for scientific research (No.10670682) from the Ministry of Education, Science and Culture of Japan, and by a research grant for intractable diseases from the Ministry of Health and Welfare of Japan.

\section{References}

1. Batista RJV, Santos JLV, Takeshita N, Bocchino L, Lima PN, Cunha MA: Partial left ventriculectomy to improve left ventricular function in end-stage heart disease. J Card Surg 1996; 11: 96-97

2. Batista RJV, Verde J, Nery P, Bocchino L, Takeshita N, Bhayana JN, et al: Partial left ventriculectomy to treat end-stage heart disease. Ann Thorac Surg 1997; 64: 634-638

3. McCarthy PM, Starling RC, Wong J, Scalia GM, Buda T, Vargo RL, et al: Early results with partial left ventriculectomy. $J$ Thorac Cardiovasc Surg 1997; 114: 755-765

4. Bocchi EA, Bellotti G, Moraes AV, Bacal F, Moreira LF, EstevesFilho A, et al: Clinical outcome after left ventricular surgical remodeling in patients with idiopathic dilated cardiomyopathy referred for heart transplantation: Short-term results. Circulation 1997; 96(Suppl II): II- $165-$ II- 172

5. Gorcsan J, Feldman AM, Kormos RL, Mandarino WA, Demetris AJ, Batista RJV: Heterogeneous immediate effects of partial left ventriculectomy on cardiac performance. Circulation 1998; 97: 839842

6. Suma H, Isomura T, Horii T, Sato T, Kikuchi N, Iwahashi K, et al: Nontransplant cardiac surgery for end-stage cardiomyopathy. $J$ Thorac Cardiovasc Surg 2000; 119: 1233-1245

7. Richardson P, McKenna W, Bristow M, Maisch B, Mautner B, O'Connell J, et al: Report of the 1995 World Health Organization/ International Society and Federation of Cardiology Task Force on the Definition and Classification of Cardiomyopathies. Circulation 1996; 93: 841-842

8. Badorff C, Noutsias M, Kühl U, Schultheiss H-P: Cell-mediated cytotoxicity in hearts with dilated cardiomyopathy: Correlation with interstitial fibrosis and foci of activated T lymphocytes. $J$ Am Coll Cardiol 1997; 29: 429-434

9. Zee-Cheng C, Tsai CC, Palmer DC, Codd JE, Pennington DG, Williams GA: High incidence of myocarditis by endomyocardial biopsy in patients with idiopathic congestive cardiomyopathy. $J \mathrm{Am}$ Coll Cardiol 1984; 3: 63-70

10. Kasper EK, Agema WRP, Hutchins GM, Deckers JW, Hare JM, Baughman KL: The causes of dilated cardiomyopathy: A clinicopathologic review of 673 consecutive patients. J Am Coll Cardiol 1994; 23: 586-590

11. Kühl U, Noutsias M, Seeberg B, Schultheiss H-P: Immunohistochemical evidence for a chronic intramyocardial inflammatory process in dilated cardiomyopathy. Heart 1996; 75: 295-300

12. Jin O, Sole MJ, Butany JW, China W-K, McLaughlin PR, Liu P, et al: Detection of enterovirus RNA in myocardial biopsies from patients with myocarditis and cardiomyopathy using gene amplification by polymerase chain reaction. Circulation 1990; 82: 8-16

13. Grasso M, Arbustini E, Silini E, Diegoli M, Percivalle E, Ratti G, et al: Search for coxsackievirus B3 RNA in idiopathic dilated cardiomyopathy using gene amplification by polymerase chain reaction. Am J Cardiol 1992; 69: 658-664

14. Koide H, Kitaura Y, Deguchi H, Ukimura A, Kawamura K, Hirai K: Genomic detection of enteroviruses in the myocardium: Studies on animal hearts with coxsackievirus B3 myocarditis and endomyocardial biopsies from patients with myocarditis and dilated cardiomyopathy. Jpn Circ J 1992; 56: 1081-1093

15. Fujioka S, Koide H, Kitaura Y, Deguchi H, Kawamura K, Hirai K: Molecular detection and differentiation of enteroviruses in endomyocardial biopsies and pericardial effusions from dilated cardiomyopathy and myocarditis. Am Heart J 1996; 131: 760-765

16. Roberts WC, Siegel RJ, McManus BM: Idiopathic dilated cardiomyopathy: Analysis of 152 necropsy patients. Am J Cardiol 1987; 60: $1340-1355$

17. Anderson KR, Sutton MG, Lie JT: Histopathological types of cardiac fibrosis in myocardial disease. J Pathol 1979; 128: 79-85

18. Terasaki F, Okabe M, Hayashi T, Fujioka S, Suwa M, Hirota Y, et al: Myocardial inflammatory cell infiltrates in cases of dilated cardiomyopathy: Light microscopic, immunohistochemical and virological analyses of myocardium specimens obtained by partial left ventriculectomy. J Card Surg 1999; 14: 141-146

19. Terasaki F, Okabe M, Hayashi T, Fujioka S, Hirota Y, Kitaura Y, et al: The presence of inflammation in cases of dilated cardiomyopathy: Immunohistochemical and virological analyses of myocardium spec- 
imens obtained by partial left ventriculectomy. In: Kawaguchi AT, Linde LM, editors. Partial left ventriculectomy: Recent evolution for safe and effective application. Amsterdam: Elsevier Science, 1999: $91-98$

20. Criteria Committee of the New York Heart Association: Disease of the heart and blood vessels: Nomenclature and criteria for diagnosis, 6th edn. Boston: Little Brown, 1964: 110

21. Noda S: Histopathology of endomyocardial biopsies from patients with idiopathic cardiomyopathy; quantitative evaluation based on multivariate statistical analysis. Jpn Circ J 1980; 44: 95-116

22. Weibel ER: Point counting methods. In: Weibel ER, editor: Stereological methods. London, UK: Academic Press Inc, 1979: 101-161

23. Fujioka S, Koide H, Kitaura Y, Deguchi H, Kawamura K: Analysis of enterovirus genotypes using single-strand conformation polymorphisms of polymerase chain reaction products. $J$ Virol Methods 1995; 51: $253-258$

24. Fujioka S, Kitaura Y, Ukimura A, Deguchi H, Kawamura K, Isomura T, et al: Evaluation of viral infection in the myocardium of patients with idiopathic dilated cardiomyopathy. J Am Coll Cardiol 2000; 36: 1920-1926

25. Stolf NAG, Moreira LFP, Bocchi EA, Higuchi ML, Bacal F, Bellotti $\mathrm{G}$, et al: Determinants of midterm outcome of partial left ventriculectomy in dilated cardiomyopathy. Ann Thorac Surg 1998; 66: 15851591

26. Holzinger C, Schoellhammer A, Imhof M, Reinwald C, Kramer G, Zuckermann A, et al: Phenotypic patterns of mononuclear cells in dilated cardiomyopathy. Circulation 1995; 92: 2876-2885

27. Noutsias M, Seeberg B, Schultheiss H-P, Kühl U: Expression of cell adhesion molecules in dilated cardiomyopathy: Evidence for endothelial activation in inflammatory cardiomyopathy. Circulation 1999; 99: $2124-2131$

28. Kawai C: From myocarditis to cardiomyopathy: Mechanisms of inflammation and cell death: Learning from the past for the future. Circulation 1999; 99: 1091-1100

29. Maisch B, Hufnagel G, Schoenian U, Hengstenberg C: The European study of epidemiology and treatment of cardiac inflammatory disease (ESETCID). Eur Heart J 1995; 16(SupplO): 173-175

30. Maisch B, Herzum M, Hufnagel G, Bethge C, Schoenian U: Immunosuppressive treatment for myocarditis and dilated cardiomyopathy. Eur Heart J 1995; 16(SupplO): 153-161

31. Kühl U, Schultheiss H-P: Treatment of chronic myocarditis with corticosteroids. Eur Heart J 1995; 16(SupplO): 168-172

32. Parrillo JE, Cunnion RE, Epstein SE, Parker MM, Suffredini AF, Brenner M, et al: A prospective, randomized, controlled trial of prednisone for dilated cardiomyopathy. N Engl J Med 1989; 321: 1061 1068

33. Mason JW, O'Connell JB, Herskowitz A, Rose NR, McManus BM, Billingham ME, et al: A clinical trial of immunosuppressive therapy for myocarditis. N Engl J Med 1995; 333: 269-275

34. Kawai S, Shimizu M, Okada R, Ih S: A morphological analysis of chronic myocarditis. Jpn Circ J 1987; 51: 1385-1392

35. Morimoto S, Yamada K, Kubo N, Mizuno Y, Hasumi M, Hiramitsu $\mathrm{S}$, et al: Clinical and pathologic features of chronic myocarditis: Four autopsy cases presenting as dilated cardiomyopathy in life. Am J Cardiovasc Pathol 1992; 4: 181-191

36. Devaux B, Scholz D, Hirche A, Kloevekorn WP, Schaper J: Upregulation of cell adhesion molecules and the presence of low grade inflammation in human chronic heart failure. Eur Heart J 1997; 18: $470-479$

37. Martino TA, Liu P, Sole MJ: Viral infection and the pathogenesis of dilated cardiomyopathy. Circ Res 1994; 74: 182-188

38. Barry WH: Mechanisms of immune-mediated myocyte injury. Circulation 1994; 89: 2421-2432 